\title{
The diet of kudus in a mopane dominated area, South Africa
}

\author{
J.F. HooimeiJer, F.A. Jansen, W.F. de Boer, D. Wessels, C. van der WaAl, C.B de Jong, \\ N.D. OTTO and L. KNOOP
}

Hooimeijer, J.F., F.A. Jansen, W.F. de Boer, D. Wessels, C. van der Waal, C.B de Jong, N.D. Otto and L. Knoop. 2005. The diet of kudus in a mopane dominated area, South Africa. Koedoe 48(2): 93-102. Pretoria. ISSN 0075-6458.

The composition of the plant species eaten by kudu (Tragelaphus strepsiceros) determines the diet quality, which impacts on kudu condition and mortality levels. The yearround diet composition of kudus in the Limpopo Province, a mopane (Colophospermum mopane) dominated area, was determined by faecal analysis. The most important dietary plant species were Colophospermum mopane, Grewia bicolor, Terminalia prunioides, Tinnea rhodesiana, Boscia albitrunca and Combretum apiculatum, with $C$. mopane comprising on average $39.2 \%$ of diet per month. Small amounts of herbs, grasses and seeds made up the remaining part of the diet. The contribution of C. mopane in the diet was negatively correlated with precipitation. Colophospermum mopane was consumed, irrespective of its high condensed tannin load $(5.2-9.8 \% \mathrm{DW})$ for the majority of the months. No seasonally significant differences were detected for modelled kudu diet crude protein, tannin or phenol concentrations. Colophospermum mopane showed significant seasonal differences with lowest values of protein, tannin and phenols in the late wet season. Surprisingly, crude protein concentrations were positively correlated with high levels of tannins and phenols for C. mopane. The diet of kudus comprised of significantly more species during the wet season compared to the dry season. Diet diversification, instead of protein maximization, seems a potential tool to satisfy protein requirements while reducing potential toxic effects associated with a high intake of secondary compounds. A significant positive correlation was therefore detected between the tannin concentration of C. mopane leaves and the number of plant species in the diet.

Key words: bushveld, condition, condensed tannin, crude protein, preference, habitat use.

J.F. Hooimeijer, F.A. Jansen, W.F. de Boer $ه$ (Fred.deBoer@wur.nl), C.vanderWaal, C.B de Jong, N.D. Otto and L. Knoop, Resource Ecology Group, Wageningen University, Bornsesteeg 69, 6708 PD Wageningen, The Netherlands; D. Wessels, University of Limpopo, Turfloop Campus, Private Bag X1106, Sovenga, 0727 Republic of South Africa.

\section{Introduction}

Due to large-scale kudu mortalities during the drought of 2002, kudu populations decreased critically in different nature areas and game ranches in northern South Africa. Mass mortality among kudus frequently occurs, and from 1981-1986 kudu mortalities were reported from numerous ranches in the dry winter months between July and September (Van Hoven 1991). Kudu population crashes commonly occur in game fenced areas in the Arid Sweet Bushveld of the Limpopo Province (Van der Waal \& Smit
2001). Previous research (Owen-Smith 1982; Owen-Smith \& Cooper 1989) showed that the dietary quality and quantity of the vegetation in kudu habitats can differ strongly per season. This variation is mainly related to rainfall and consequently forage availability. Owen-Smith \& Cooper (1989) showed that food quality and availability decrease in the dry season (May-October), and that the estimated metabolisable energy intake falls below the nutritional requirements of the kudu during this period. The nutritional gain can be reduced by the amount of secondary plant compounds like poly-phenols which 
includes condensed tannins. Diet quality in deciduous savannas is expected to differ significantly between the wet and the dry season, and might therefore offer an explanation for the observed mass mortality kudus suffered, rather than simple lack of food. The first hypothesis that will be tested in this study is that kudu diet quality (measured by crude protein, tannin, and phenol concentrations) is lower in the dry season compared to the wet season; do kudus maximise protein or minimise secondary compounds?

The study area is situated in the Mopani veld (Acocks 1988), of the northern part of the Limpopo Province. Mopani veld is generally regarded as valuable browse (Walker 1980). Colophospermum mopane, a winter deciduous tree species, has a variable leaf carriage period that may continue through the dry season into the next wet season. Due to its dominance, C. mopane is expected to play an important role in the kudu diet. Colophospermum mopane is known for its antifeedants, like polyphenolic compounds, e.g. condensed tannins (Macala et al. 1992). Tannins bind with dietary, enzymatic and microbial protein to form insoluble complexes that are not degraded in the rumen, resulting in a reduced digestibility and intake. Information on the fate of tannin-protein complexes postrumen varies and kidney, liver and gastrointestinal tract damage in animals consuming tanniferous forage has been reported (Bailey 1978). Cooper \& Owen-Smith (1985) found that plant species with condensed tannin content of $>5 \%$ leaf dry weight are preferably avoided by kudu in a non-mopane area. Van Hoven (1991) investigated kudu mortalities during winter in savanna areas of South Africa, covering drought conditions, and revealed significant correlations between kudu mortality, kudu density, and tannin content of the browse. It is therefore expected that in the rainy season, when forage availability is high, deciduous $C$. mopane is avoided by kudus due to its high tannin content. The high forage availability during the rainy season enables the kudu to select for high quality alternative browse. The kudu diet composition is therefore expected to consist only of high quality species. Subse- quently, species with a tannin content $>5 \%$ are not expected in the rainy season diet. Rainfall influences forage availability, and diet choices, and thereby stocking rates (Bothma et al. 2004). Due to the high availability of $C$. mopane during the dry season, we hypothesise that the contribution of C. mopane to the kudu diet increases in the dry season, resulting in a negative relation between rainfall and percentage $C$. mopane material in the kudu faeces.

In this study, the year-round diet of kudus in a mopane (Colophospermum mopane) dominated area is analysed through faecal analysis. This microhistological examination of herbivore droppings provides an estimate of the ingested biomass per plant taxon (Stewart 1967; Sparks \& Malechek 1968; Cid \& Brizuela 1990; Bartolome et al. 1995). To this end, epidermis fragments of ingested plants in the faeces are compared to photomicrographs of epidermis fragments on reference slides. This is possible because the plant cuticle, an indigestible layer covering the epidermis, bears a specific pattern of underlying epidermal cells and hairs along with structures of its own (Stace 1965). This pattern can be identified down to genus or species level, even after passage through the herbivore gut.

\section{Study area}

The study was conducted on the Messina Experimental Farm, situated along the Limpopo River $\left(22^{\circ} 12^{\prime} \mathrm{S}\right.$ and $\left.29^{\circ} 50^{\prime} \mathrm{E}\right)$, within the central zone of the Limpopo Belt. The study area covers $6991 \mathrm{ha}$, and is divided by a game-proof fence into a northern game section (4605 ha) and a southern cattle section (2386 ha), with kudu occurring in both sections. The mean annual rainfall is $357 \mathrm{~mm}$ (measured over a 66-year period from $1927 / 1928$ to $1993 / 1994)$. The coefficient of variation for the total annual rainfall is $36 \%$, indicating a high frequency of droughts. Of the total annual rainfall, $75 \%$ is recorded during the period November-March. The mean daily maximum temperature varies from $25^{\circ} \mathrm{C}$ in July to $34^{\circ} \mathrm{C}$ in January; win- 
ter temperatures can be regarded as moderate (Dekker \& Van Rooyen 1995).

The study area falls within the northern block of the Mopani veld or Colophospermum mopane-Acacia nigrescens Savanna type, where $C$. mopane is the dominant tree species (Dekker \& Van Rooyen 1995). The vegetation in the study area is relatively homogeneous. In total, 183 plant species were recorded in eight distinct plant communities (Dekker \& Van Rooyen 1995). The browse availability on the Messina Experimental Farm was determined by Dekker \& Smit (1996) in both the northern and southern section. The total leaf $\mathrm{DM}$ ranged between $1224 \mathrm{~kg} / \mathrm{ha}$ and $2672 \mathrm{~kg} / \mathrm{ha}$ (Dekker $\&$ Smit 1996). Colophospermum mopane contributed substantially to the total leaf DM in all communities.

The kudu population size in the game section, determined by a helicopter game count in 2002, approached a hundred. No major off-takes or mortalities occurred since then (Cornelis van der Waal pers. comm. 2005).

\section{Materials and Methods}

\section{Faecal analyses}

The leaves of over a 100 species of potential food plants occurring on the Messina Experimental Farm were sampled for a reference collection. Pieces of relevant parts (foliage, seeds and fruits) were cleaned in household bleach overnight, washed in water, and fragments of epidermis stripped off and mounted in glycerol. Photographs of these slides were used to identify the fragments of cuticle observed in samples of kudu faeces. The magnification ranged from 200-400 times, depending on cell, hair or stomata size of the epidermis fragment. The cuticles on mature green plant parts show the pattern of the epidermis cells they cover. Very young undeveloped cuticles present in the dung samples may show no imprints of the epidermis cells in which case no identification was possible. Also, soft cuticles may get crinkled beyond recognition. However, often hairs, glands or specific patterns were present on the cuticle itself which allowed identification of a given species. Digestibility of plant parts as such bore no relation to recognition of cuticle or epidermis fragments. Due to its chemical composition, plant cuticle is indigestible in any animal's guts (Stace 1965). This applies to the leaves of trees and grasses as much as to forbs.

The faecal analysis was carried out on monthly collected mixed faecal samples of kudu droppings from June 2003 to May 2004. Individual pellet groups are not independent samples of the diet of a single animal (Lewis 1994); the availability of food items changes with increasing consumption, thereby influencing diet composition. Also, herbivores vary their choice of food plants between meals in order to maintain a varied diet, and to limit consumption of secondary chemicals (Freeland 1991, McArthur and others 1991); McArthur et al. 1991). Each mixed sample consisted of three or more sub-samples, which were randomly collected in the study area. Every sub-sample consisted of five fresh ( $<24$ hours old) kudu pellets. All collected sub-samples from the same month were pooled and thoroughly mixed. The mixed pellet samples were heated under pressure to $115^{\circ} \mathrm{C}$ in water for \pm 2 hours, and left to soak overnight. A sub-sample was washed in a blender, and strained over a plankton sieve, then preserved in $70 \%$ ethanol. The samples were analysed by using a microscope, and at least 100 cuticle or epidermis fragments in each sample were identified by comparison with the reference collection. The surface area of individual fragments was estimated by counting the obstructed grid cells $\left(0.01 \mathrm{~mm}^{2}\right.$ per cell) in the microscopic field of view (De Jong et al. 2004). The abundance of each species was calculated as a percentage of the total area of the fragments measured (De Jong et al. 2004). Encountered grass species in the faeces were placed into one category as the amount of consumed grasses was relatively low and their nutritional value assumed to be similar.

\section{Diet quality}

Foliage samples of the most important dietary plant species ( $n=5$; comprising $66 \%$ of the kudu diet) were collected in the field for quality analysis by the University of Limpopo from December 2002 till June 2004. Seven fresh leaves were randomly collected at kudu browse height from the canopies of 40 randomly selected trees, in each sample cycle of 55 days. The bias of this hand-sampling method is unknown. Samples were transported in plastic bags to the laboratory in a cooler box where they were dried in plant presses in the shade at room temperature (Mueller-Harvey 2001; Hagerman 2002). The dried leaves were thoroughly mixed, and a pooled sample of $10 \mathrm{~g}$ per treatment per sample cycle (55 days) was sent to the Botany Department, Universi- 
ty of Cape Town, for the determination of total phenolics, condensed tannins and crude protein. All parameter values were measured in $\% \mathrm{DW}$, phenol content was based on GAE (Gallic acid equivalents) and condensed tannin content on STE (Sorghum tannin equivalents) as described by Hagerman (2002). Additional nutritional data $(n=5$; comprising $24 \%$ of the kudu diet) were obtained from other sources (Aganga \& Adolga-Bessa 1999; Aganga \& Mosase 2001; Fustenburg \& van Hoven 1994; Lagendijk 2003) or retrieved from the Animal Feed Recourses Information System (AFRIS) (FAO 2004). Dietary species were classified into four groups: deciduous woody, evergreen woody, forbs and others. A monthly class average per nutritional parameter was used for species for which no nutritional data was available ( $9 \%$ of the kudu diet). The diet quality, in terms of condensed tannins crude protein, and total phenolics was calculated using $\Sigma\left(x_{\mathrm{i}}{ }^{*}\right.$ perc $\left.\mathrm{i}_{\mathrm{i}}\right)$ with $x_{\mathrm{i}}$ as the bi-monthly average value of the quality parameter (condensed tannin, crude protein, or phenol) per plant species $i$ and $\operatorname{perc}_{\mathrm{i}}$ as the mean monthly percentage of occurrence of a plant species $i$ in the diet, similar to Owen-Smith \& Cooper (1989). Climatic data were obtained from the South African Weather Service which were measured at the Macuville weather station (No. 0809706X), situated on the Messina Experimental Farm.

\section{Statistical analysis}

Anovas were carried out using as dependent variables, the mean values recorded per month for species richness (averaged from the different samples) or the monthly mean diet quality parameters. As dependent variables did not violate basic assumption for normality (Kolmogorov-Smirnov test) and equality of variances (Levene's test), Anovas were carried out to test for seasonal difference, using SPSS (v12), followed by a Tukey multiple comparison test (Zar 1984).

\section{Results}

\section{Kudu diet: species composition}

The fragments of 20 dicotyledonous species contributed $82 \%$ of the analysed kudu faecal samples and, together with the grass species, comprised $96.6 \%$ of a full year's samples (Table 1). The remaining $3.4 \%$ consisted of species which were only encountered once and were therefore not included in the diet quality analyses. Colophospermum mopane was the most prominent in the faecal samples; it was consumed each month in relatively large amounts, with an annual average

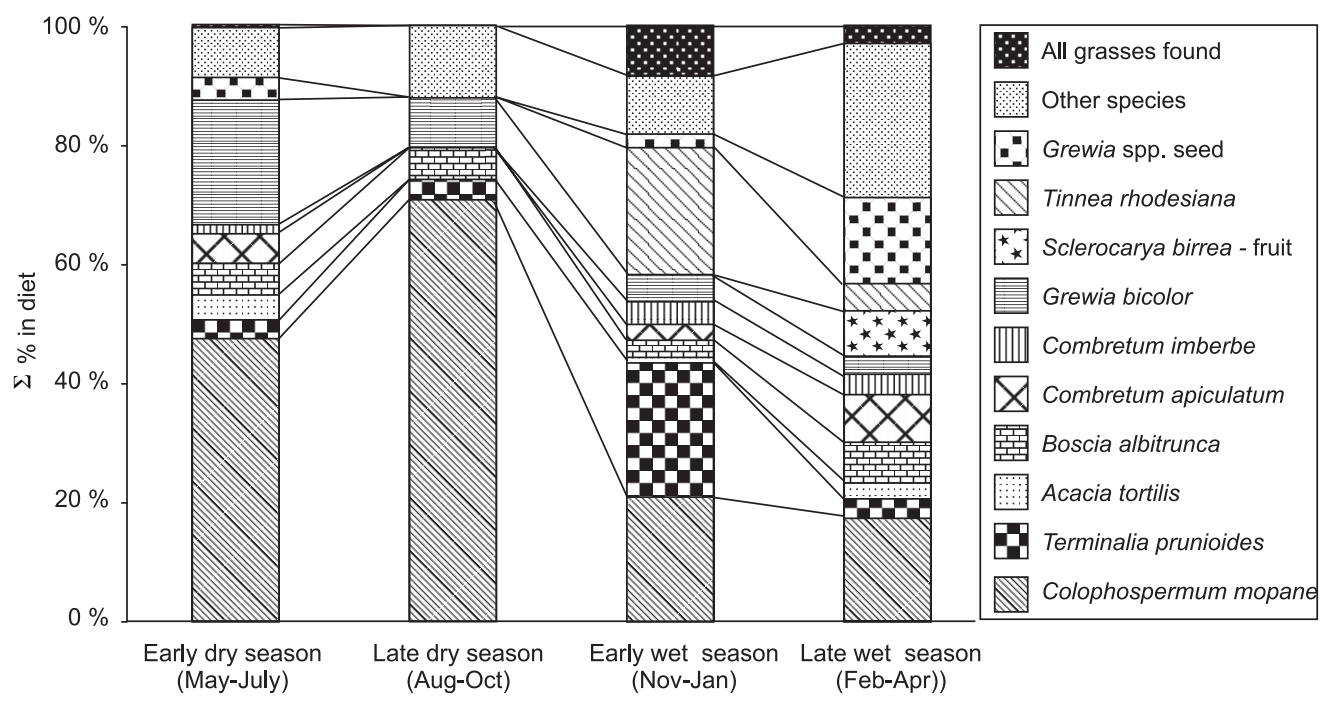

Fig. 1. Seasonal differences of kudu diet composition for the main (annual $>1.9 \%$ ) dietary species. 


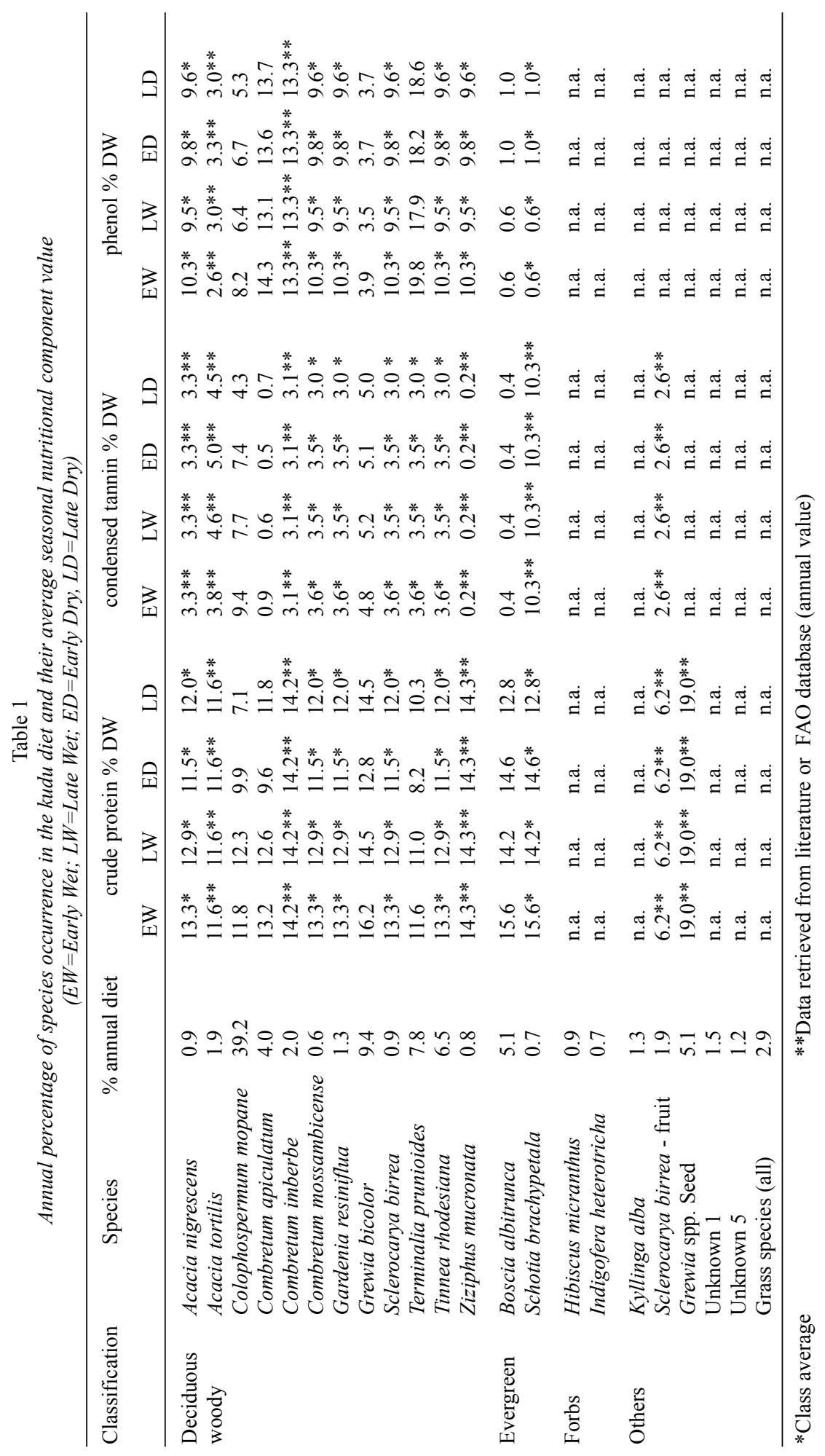


of almost $40 \%$. The percentage of mopane in the diet was the highest during the late dry season (August-November) (Fig 1.), reaching a peak of $91 \%$ in September. The contribution of $C$. mopane to the diet was always $>16 \%$, except for March when it dropped to $3 \%$ and was replaced by Combretum apiculatum. Besides C. mopane, only six species comprised $>5 \%$ of the kudu diet when averaged over the year; these were Grewia bicolor $(9.4 \%)$, Terminalia prunioides $(7.8 \%)$, Tinnea rhodesiana (6.5\%), Boscia albitrun$c a$, and Grewia spp. seeds (5.1\%). Grass species were only eaten at the beginning of the wet season, with a maximum contribution of $13.5 \%$ in samples in December. The percentage of grasses in samples declined as the wet season progressed. In February, when the fruits of Sclerocarya birrea (marula) ripened (late wet season), large quantities were found in the dung samples which peaked at $16 \%$ contribution in this month's samples.

The contribution of $C$. mopane in the kudu faecal samples could be best explained by a quadratic regression model in which the

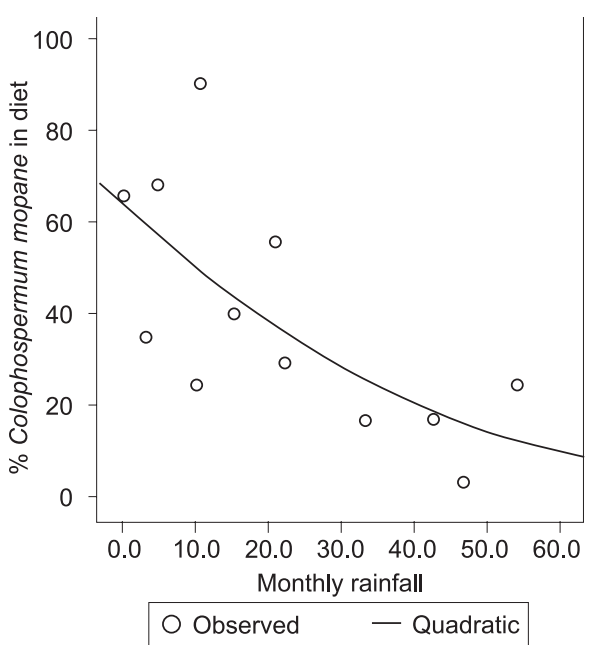

Fig 2. Relationship between monthly amount of rainfall (mm) and \% of Colophospermum mopane leaf material in the diet of kudus. monthly percentage of $C$. mopane in the diet was significantly related to the monthly precipitation records $(n=12 ; \quad \mathrm{F}=4.03$; $P<0.05 ; r^{2}=0,472$; Fig. 2).

The number of dietary species during the dry season was relatively stable and ranged from eight to 13 between months. During the wet season, the contribution of other species gradually increased from 15 species in December to 25 in April, including the species encountered only once. The average number of different species recorded in the faecal samples in the dry season was 10.8 , which is significantly lower than the 18.2 consumed during the wet season (Anova, $\left.\mathrm{F}_{1,10}=8.417 ; P<0.02\right)$.

\section{Diet quality}

The calculated crude protein content declined in the late dry season and reached its minimum $(6.2 \% \mathrm{DW})$ in October. In the late wet season (May 2004), the maximum crude protein values recorded were $12.6 \%$ DW, corresponding to the month with the highest number of species found in the diet (Table 1). Surprisingly, no significant differences (Anova, $\mathrm{F}_{3,8}<3.583 ; P>5 \%$ ) could be found in average $\mathrm{CP}$, tannin or phenol concentrations between the wet and dry season, probably because high diet $\mathrm{CP}$ persisted quite long into the dry season, as shown in Table 2. However, when the analysis was repeated for the dominant diet species $(C$. mopane) only, significant differences were detected, with significantly lower values of $\mathrm{CP}$, tannins, and phenols in the late dry season compared to the wet seasons (Anova, $\mathrm{F}_{3,8}>6.664 ; P<0.03$; with a Tukey post hoc test at $5 \%$ ).

Condensed tannin content, projected for the diet, generally followed the same trend as crude protein levels with low levels in the late wet and late dry seasons (Table 2). No significant seasonal difference could be detected for average tannin levels. Measured condensed tannin levels in C. mopane were only $3.8 \% \mathrm{DW}$ in October/November (annual lowest), but the tannin values more than doubled in December/January to $9.8 \%$ DW, 
Table 2

Diet quality estimates in terms of crude protein, condensed tannins and phenol

\begin{tabular}{llccc}
\hline Season & Month & \multicolumn{3}{c}{ Nutritional component (\%) } \\
\cline { 3 - 5 } & & $\begin{array}{c}\text { Crude } \\
\text { protein }\end{array}$ & $\begin{array}{c}\text { Condensed } \\
\text { tannin }\end{array}$ & Phenol \\
\hline Early wet & January & 11.1 & 4.9 & 8.0 \\
Early wet & February & 10.1 & 3.7 & 3.5 \\
Late wet & March & 10.0 & 2.0 & 4.2 \\
Late wet & April & 10.6 & 3.3 & 5.2 \\
Late wet & May & 12.6 & 4.2 & 6.0 \\
Early dry & June & 11.0 & 5.8 & 5.6 \\
Early dry & July & 10.5 & 7.0 & 6.8 \\
Early dry & August & 10.6 & 4.7 & 6.3 \\
Late dry & September & 9.5 & 4.9 & 5.8 \\
Late dry & October & 6.2 & 2.5 & 3.6 \\
Late dry & November & 9.4 & 3.0 & 13.0 \\
Early wet & December & 11.3 & 3.7 & 7.5 \\
\hline
\end{tabular}

when the percentage of $C$. mopane in the diet declined to $16 \%$. Condensed tannin levels in mopane leaves were between $7.2-9.8 \%$ for the entire period between December and July.

The other species were lower in tannin levels than $C$. mopane, normally $<5 \%$ (Table 1 ), except for Schotia brachypetala, with estimated levels around $10 \%$. Mopane tannin content increased significantly concomitant with crude protein levels (Spearman-r $=$ $0.657 ; P<0.05 ; n=12)$. However, no significant correlation between tannin and crude protein, comprising all species, could be detected (Spearman-r $=0.399 ; P>0.05$; $n=12$ ).

Phenol content varied over the season; in November the estimated dietary phenol content reached a peak of $13.0 \% \mathrm{DW}$, caused by a large amount of Terminalia prunioides $(62.7 \%)$ in the diet. Terminalia prunioides and Combretum apiculatum had higher phenol levels than $C$. mopane throughout the year. Lowest dietary phenol levels were recorded in February at $3.5 \%$. The phenol content of only $C$. mopane increased significantly with CP levels (Spearman-r $=0.600$; $P<0.05 ; n=12)$. No significant correlation could be found between the percentage occurrence of $C$. mopane foliage in the diet of kudu and any of the other three parameters of $C$. mopane foliage quality (Spearman test).

\section{Discussion}

Owen-Smith \& Cooper (1987) stated that the local soil nutrient status is an important factor in influencing plant defence mechanisms against herbivory. The majority of our forage quality estimates was obtained from field samples, but some literature data were used as well, which may not be representative for the quality of the species occurring in the study area. Hence, it is possible that the results of the diet quality estimates might deviate from actual values. Another point of discussion is the availability of the different forage species, which was not measured in this study, and could also influence kudu diet selection. So, further research is needed to support the general validity of our findings.

We found that the diet quality between the wet season and dry season was not significant in terms of CP, tannin or phenol content. Dekker \& Smit (1995) revealed that browse availability in the study area is lowest from September to November (late dry season). During the same period, estimated dietary crude protein levels reached a minimum with CP levels varying between 6.2-9.5\% between months. As was hypothesised, the contribution of $C$. mopane to the kudu diet peaked during this period of limited forage availability. The large contribution to the kudu diet and the long leaf carriage period of $C$. mopane, which often appears as early as September with leaf senescence starting as late as June (Dekker \& Smit 1995), illustrates that $C$. mopane is the most important species in the kudu diet. Dekker \& Smit (1995) also noticed that the long leaf carriage period of $C$. mopane, rela- 
tive to other tree species, underlies its potential value as a fodder resource in the study area. The expected correlation between increased intake of $C$. mopane foliage and decreasing rainfall was confirmed in this study, and followed a quadratic relationship. Several parallels with research on kudu of the Nylsvley Nature Reserve, where Burkea africana and Ochna pulchra are dominant tree/shrub species (Owen-Smith \& Cooper 1988), could be noticed. Their study, conducted at the Nylsvley Nature Reserve showed that during the late wet season forbs comprised circa half the diet, but during the course of the dry season, foliage of palatable evergreen species became the most important dietary component. Our study also revealed that the species that were generally favoured became more important during the course of the dry season, forbs however showed to be less favoured in comparison to the Nylsvley study. Both studies showed that fruits and seeds were often eaten/selected, but comprised a minor part of the diet. Grass consumption also revealed a similar pattern; grasses were only consumed at the beginning of the wet seasons, and grass intake decreased as the season progressed.

Kudu browse not only on foliage, but also on the supporting twigs and shoots. Histological faecal analyses can only identify foliage, fruit and seed fragments with certainty. The woody twig material in the diet was therefore not considered. Stems and twigs are of a lower quality than foliage and, as our diet quality calculations were based on leaf quality data only, we might have over-estimated the diet quality. Other determinants such as trace elements, not included in this study, might also influence the browsing behaviour and nutritional gain of kudu in the Mopani veld of the Limpopo Province.

However, the quality of $C$. mopane was significantly different in the late dry period, with lowest values of $\mathrm{CP}$, tannins and phenols. Measured condensed tannin levels of C. mopane were above $7.2 \% \mathrm{DW}$ except between September and November (3.8$5.2 \% \mathrm{DW})$. These findings do not match the results of Cooper \& Owen Smith (1985), who found in their study at Nylsvley that plant species with condensed tannin contents $>5 \%$ of leaf dry mass are preferentially avoided by kudu, except in periods when little other food was available. At the onset of the wet season the contribution of $C$. mopane declined as expected but still formed a substantial part of the diet. Apparently kudus do not reject $C$. mopane foliage due to high tannin concentrations. The question is of course, do they have a choice; is the forage availability sufficiently large to enable to switch diet to species with a lower tannin content? The fact that $C$. mopane formed a substantial part of the kudu diet during the wet season proves that tannin-rich species are not avoided when food availability is sufficiently large. High condensed tannin levels do not seem to pose a threshold limiting browse consumption by kudu in the study area. In fact, the coupling between crude protein levels and secondary compounds is remarkable, and the tannin content does not increase with the building-up of structural carbohydrates in the dry season. This atypical pattern in mopane is confirmed in recent studies (Wessels et al., in prep.).

Sinclair (1975) and Owen-Smith (1982) showed that during the season of active vegetation growth, herbivores are surrounded by an abundance of potential food in the form of plant foliage. We found that the number of species comprising the kudu diet increased at the beginning of the wet season. Kudus seem to select for diet quality, but are restricted in their choices by the availability of species in their habitat. However, during the dry or cold season when many deciduous plants are dormant, food availability decreases drastically in both quantity and quality. Against a background of low forage availability and quality the timing of leaf flushes and the ripening of fruits therefore have an important influence on dietary composition, as could be seen in this study by the increased intake of Grewia seeds, Sclerocarya birrea fruits, and Terminalia prunioides leaves the moment they became available. Owen Smith \& Novellie (1982) found that kudu exhibited a tendency to widen their diet as the dry season advanced. They suggested that kudus were 
limited more by the availability of food than by the effects of food quality on digestive rates. However, our study showed that the number of species in the kudu diet increases significantly during the wet season compared to the dry season. Hence, we can conclude that kudus do not restrict their diet to quality-rich species only in times of high forage availability. This pattern of a broad diet in times of plenty and a restricted diet when the food availability and quality is reduced, is not a pattern predicted by the optimal foraging theory in terms of nutrient or energy maximisation (Stephens \& Krebs 1986), but seem to follow the idea, also illustrated in Owen-Smith \& Cooper (1987), that dietary thresholds are more important than optimisation. However, forage availability and quality are confounded in this study, and therefore calls for controlled feeding experiments in order to be able to separate the unique effect of forage availability and forage quality on kudu diet selection. Except for the low forage availability, and therefore limited potential of alternative forage species in the dry season, an alternative hypothesis might be found in the positive correlation between protein levels and tannin and phenol concentration. Choosing for high protein forage automatically increases the concentration of the secondary compounds in the diet. In order to avoid toxic effects, kudus seem to follow the satiety hypothesis (Provenza et al. 2003), and diversify their diet in the wet season, leading to an increased number of species in the period that secondary compound concentrations are at its highest. Owen Smith \& Novellie (1982) also suggested that large herbivores need to restrict their intakes of various potential toxins below certain maximum thresholds, and that this could be an important factor promoting varied diets. In fact, we found a significant positive correlation between the condensed tannin concentration of $C$. mopane leaves and the total number of species in the diet $\left(\mathrm{r}_{\mathrm{s}}=0.701, P<0.01, n=12\right)$; the higher the tannin concentration, the more forage species the kudus consumed. This diversification could also be an alternative explanation for the fact that the average diet crude protein concentration was not larger during the wet season. A diverse diet, spreading the risk of an excessive intake of secondary compounds, seems more important than maximising protein intake.

\section{Acknowledgements}

Special thanks go to Chris Kellermann for providing us with the data of the chemical analyses. Furthermore we wish to thank Norman Owen-Smith for his invaluable comments and advice on the article. Willemien Luus-Powel and Martin Potgieter are thanked for various forms of assistance. This research was supported by grants from the DELTA scholarships, the FONA Foundation for Research and Nature Conservation, ESKOM-TESP, NRF Pretoria and the United Kingdom Department for International Development (DFID) [Reference Number: R7822]. Project title: Mopane Woodlands and the Mopane Worm: Enhancing Rural Livelihoods and Resource Sustainability for the benefit of developing countries. The views expressed are not necessarily those of DFID. The University of Limpopo is thanked for various forms of assistance and the Department of Agriculture, Limpopo Province for permission to conduct research on the Messina Experimental Farm.

\section{References}

Acocks, J.P.H. 1988. Veld types of South Africa. 2nd Edition. Memoirs of the botanical Survey of South Africa 57.

Aganga, A.A. \& T. Adogla-Bessa. 1999. Dry matter degradation, tannin and crude protein contents of some indigenous browse plants of Botswana. Archivos de Zootecnica 48(181): 79-83.

Aganga, A.A. \& K.W. Mosase. 2001. Tannin content, nutritive value and dry matter digestibility of Lonchocarpus capassa, Zizyphus mucronata, Sclerocarya birrea, Kirkia acuminata and Rhus lancea seeds. Animal Feed Science and Technology 91: 107-113.

BAILEY, E.M. 1978. Physiologic response of livestock to toxic plants. Journal of Range Management 31: 343-347.

Bartolome, J., J. Franch, M. Gutman \& N.G. SEligman. 1995 Physical factors that influence fecal analysis estimates of herbivore diets. Journal of Range Management 48: 267-270.

BothMA, J. DU P., N. VAN ROOYEN \& M.W. VAN RoOYEn. 2004 Using diet and plant resources to 
set wildlife stocking densities in African savannas. Wildlife-Society-Bulletin 32: 840-851.

Cid, M.S. \& M.A. BRIzuElA. 1990. Grass blade and sheath quantification by microhistological analysis. Journal of Wildlife Management 54: 349-352.

Cooper, S.M. \& N. Owen-Smith. 1985. Condensed tannins deter feeding by browsing ruminants in a South African savanna. Oecologia 67: 142-146.

De Jong, C.B., S.E. van Wieren, R.M.A. Gill \& R. MunRo. 2004. Relationship between diet and liver carcinomas in roe deer in Kielder Forest and Galloway Forest. Veterinary Record 155: 197-200.

DeKker, B. \& N. van RoOyen. 1995. The physical environment and plant communities of the Messina Experimental Farm. South African Journal of Botany 61(3): 158-167.

DeKKeR, B. \& G.N. SMit. 1996. Browse production and leaf phenology of some trees and shrubs in different Colophospermum mopane savanna communities. African Journal of Range \& Forage Science 13(1): 15-23.

Food AND Agriculture ORGANIZATION OF THE UNITED NATIONS (FAO), homepage. www.fao.org. http://www.fao.org/ag/AGA/AGAP/FRG/afris/i ndex_en.htm (15-12-04).

FurstenBurg, D. \& W. van Hoven. 1994. Condensed tannin as anti-defoliate agent against browsing by giraffe (Giraffa cameleopardalis) in the Kruger National Park. Comparative Biochemistry and Physiology 107A: 425-431.

FREELAND, W. J. 1991. Plant secondary metabolites: biochemical coevolution with herbivores. Pp. 61-81. In: PALO, R.T. \& C.T. RoBbins (eds.). Plant Defenses Against Mammalian Herbivory. Boca Raton: CRC Press.

Hagerman, A.E. 2002. Tannin handbook. http:// www.users.muohio.edu/hagermae/ (05-06-05)

LAGENDIJK, D.D.G. 2003. Mopane woodlands: a food source for elephants. MSc thesis, Wageningen University, Wageningen.

LEWIS, S.W. 1994. Fecal and rumen analyses in relation to temporal variation in black-tailed deer diets. Journal of Wildlife Management 58: 53-58.

Macala, J., B. Sebolai \& R.R. Majinda. 1992. Colophospermum mopane browse plant and sorghum stover as feed resources for ruminants during the dry season in Botswana. Pp. 151-161. In: Stares, J.E.S., A.N. SaID \& J.A. Kategile (eds.). The complimentary of feed resources for animal production in Africa. Proceedings of the joint feed resources network workshop. ILCA, Addis Ababa, Ethiopia.

McArthur, C., A. Hagerman \& C.T. Robbins. 1991. Physiological strategies of mammalian herbivores against plant defenses. Pp. 103-114. In: PAlo, R.T. \& C.T. RobBins (eds.). Plant Defenses Against Mammalian Herbivory. Boca Raton: CRC Press.
Mueller-Harvey, I. 2001. Analysis of hydrolysable tannins. Animal Feed Science and Technology 91: 3-20.

Owen-SMith, N. 1982. Factors influencing the consumption of plant products by large herbivores. Pp. 359-404. In: Huntley, B.J. \& B.H. WALKER (eds.). The ecology of tropical savannas. Berlin, Germany: Springer-Verlag.

Owen-Smith, N. \& S. CoOper. 1987. Palatability of woody plants to browsing ruminants in a South African savanna. Ecology 68(2): 319-331.

Owen-Smith, N. \& S. CoOper. 1989. Nutritional ecology of a browsing ruminant, the kudu (Tragelaphus strepsiceros), through the seasonal cycle. The Zoological Society of London 219: 29-43.

Owen-Smith, N. \& P. Novellie. 1982. What should a clever ungulate eat? American Naturalist 119: 151-178.

OWEN-SMith, N. 2002. Adaptive herbivore ecology: from resources to populations in variable environments. Cambridge: Cambridge University Press.

Provenza F.D, J.J. Villalba \& R.E. Banner. 2003. Linking herbivore experience, varied diets, and plant biochemical diversity. Small ruminant research 49(3): 257-274.

SinClAIR, A.R.E. 1975. The resource limitation of trophic levels in tropical grassland ecosystems. Journal of Animal Ecology 44: 497-520.

SPARKS, D.R. \& C. MALECHEK. 1968. Estimating percentage dry weight in diets using a microscopic technique. Journal of Range Management 21: 264-265.

StaCe, C.A. 1965. Cuticular studies as an aid to plant taxonomy. Bulletin of the British Museum (Natural History) Botany 4: 1-78.

StewART, D.R.M. 1967. Analysis of plant epidermis in faeces: a technique for studying the food preferences of grazing herbivores. Journal of Applied Ecology 4: 83-111.

Stephens, D.W. \& J.R. KREBS. 1986. Foraging theory. Princeton: Princeton University Press.

VAn Hoven, W. 1991. Mortalities in Kudu (Tragelaphus strepsiceros) populations related to chemical defence of trees. Revue de Zoologie Africaine 105: 141-145.

VAn Der WaAl, C., \& G.N. Smit. 2001. Relations between kudu mortalities and woody browse availability in a semi-arid savanna. Pp. 38-43. In: Ebedes, H., B. Reilly, W. van Hoven \& B. Penzhorn (eds.). Sustainable utilisation - Conservation in practice. Pretoria: South African Game Ranchers' Organisation.

WALKER, B.H. 1980. A review of browse and its role in livestock production in Southern Africa. Browse in Africa, the current state of knowledge. Addis Ababa: ILCA.

ZAR, J.H. 1984. Biostatistical Analysis. London: Prentice Hall. 